\title{
Building a hidden investment state? The European Investment Bank, national development banks and European economic governance
}

\author{
Daniel Mertens ${ }^{\mathrm{a}}$ and Matthias Thiemann ${ }^{\mathrm{b}}$ \\ anstitute of Political Science, Goethe University, Frankfurt am Main, Germany; \\ ${ }^{b}$ SciencesPo, Centre d'études européennes, Paris, France
}

\begin{abstract}
The European Commission's Investment Plan for Europe and the enduring economic crisis has brought state-owned development banks again to the fore of public and scholarly debate in Europe. This article proposes to place these banks' activities and recent institutional co-operation in the context of European integration and assumes a historical perspective on European economic governance and development banking. Most importantly, it argues that the European Investment Bank has become a centre of gravity in long-standing political attempts to increase the investment firepower of the European Union. Based on detailed process-tracing analysis through publicly available data and interview material, the article delineates a gradual process of institutional innovation and network formation that advanced since the late 1980s and culminated in recent post-crisis policy processes. The contemporary visibility of development banking in Europe, we conclude, follows from these and is representative of a nucleus for a - somewhat hidden - European investment state, whose reach and stability, however, is yet to be determined.
\end{abstract}

\section{KEYWORDS}

EIB; EIF; economic governance; European Commission; Investment Plan for Europe; public banking

\section{Introduction}

The post-crisis restructuring of the European economy has brought political and academic attention to a heretofore rather backstage operating actor in the financial landscape, state-owned development banks. ${ }^{1}$ The European Investment Bank (EIB), which is the multilateral development bank of the European Union (EU), as well as national development banks (NDBs) were called upon by policy-makers to expand their activities to fuel investment across the Union. Accordingly, most of these banks expanded their balance sheets significantly between 2007 and 2014: the ElB increased its assets by almost 100 per cent, the large Italian Cassa Depositi e Prestiti (CDP) and German Kreditanstalt für Wiederaufbau (KfW) by roughly 80 and 40 per 
cent respectively, and a small NDB like the Finnish Finnvera by a staggering 275 per cent. ${ }^{2}$ Simultaneously, one could observe a new wave of institutional diffusion of development banks in Europe. Since 2010, several member states have engaged in founding new financial institutions that promote socioeconomic development - among them Ireland (Strategic Banking Corporation of Ireland in 2014), Portugal (Instituição Financeira de Desenvolvimento in 2014) and the United Kingdom (UK) (British Business Bank and Green Investment Bank in 2012) - such that every EU country today holds at its behest one such institution or is amid the founding process (DG Internal Policies 2016a).

The importance of development banks to the current European political economy came to the fore after Jean-Claude Juncker's election as President of the European Commission (EC) in November 2014, when the Investment Plan for Europe and its European Fund for Strategic Investment (EFSI) became the prime attempt to bolster economic recovery in the EU. A key feature of this plan was its implementation through the ElB that was equipped to leverage funds from the EU budget to mobilize private investment. Furthermore, NDBs received positions as both stakeholders and contributors, on which the success of the plan was said to hinge critically (European Commission 2014; European Commission 2015b). Surprisingly, scholars of European integration and political economy have not reflected much on these observations yet. Those contributions tackling the growing importance and role of development banks in the European Union have mainly welcomed and advocated this trend, explaining it by the counter-cyclical function these banks traditionally fulfil (Griffith-Jones and Cozzi 2016; Griffith-Jones and Tyson 2013; Kollatz-Ahnen 2015; Mazzucato and Penna 2016). ${ }^{3}$

However, this functional explanation misses important points about the institutional evolution of European economic governance and the historical trajectory of development banking in the European political economy. The fact that, before the crisis, state banking was severely under pressure of European liberalization policies and even declared near death (Seikel 2014; Verdier 2000) begs for historical and political placement of recent events. The outlined growth of the EIB and its national counterparts, this article therefore contends, is significantly rooted in two parallel processes of European integration. First, it is intrinsically linked to a long-standing political quest for a European investment state that compensates poor fiscal capacity on the supranational level. Development banks, in this sense, have become increasingly relevant to create a governmental infrastructure that ties together the fragmented landscape of European economic policy-making. Second, the recent diffusion and activities of development banks rest on a historical lineage of innovating financial instruments that depart from the traditional business of subsidized lending and instead tap European budgetary resources based on leveraging and revolving funds. Again, this has gradually allowed for intensified coordination between different levels of policy-making in Europe. Importantly, 
in both realms, the financial and economic crisis has served as a catalyst of these processes, but was not their original driver. Rather, the EC's Investment Plan for Europe interlocked several less-visible institutional and policy-making tendencies of the last three decades into what might be the nucleus of a European investment state. In its basic tenet, this investment state provides a gradually built multilevel infrastructure for furthering investment, allowing supranational, national and subnational actors such as development banks to 'make use of Europe' (Woll and Jacquot 2010) by channelling leveraged funds into the 'real economy'.

To develop this argument, the article proceeds as follows. The next section reviews the literature on development banking in the European political economy and proposes several theoretical avenues to make our observations fruitful for debates on European integration more generally. We then move on to follow the evolution of the EIB and NDBs within European economic governance through four historical sections, based on process-tracing methods and both document analysis and expert interviews (see Appendix). This diachronic approach enables us to juxtapose qualitative transformations such as the formation of new institutional ties between development banks, the EC and member states with gradual adjustments in development bank activity. These sections will concomitantly discuss these trends in European development banking in the light of several pillars of current economic governance, including the reform of fiscal capacity, state-aid regulations and subsidiarity, arguing that they coalesce to provide the ground for a hidden European investment state on which we conclude.

\section{Development banks in the European political economy}

State-owned development banks have the 'mission' to promote pre-defined socioeconomic goals. Their role, institutional set-up, and size have differed significantly across countries and are closely linked to the historical trajectory of national political economies and their distinctive public-private financial networks to furnish growth and development (Shonfield 1965; Zysman 1983). The literature on European economic governance has largely ignored their specifics, instead just noting their conflict with a liberal European order. An emerging body of literature on the role NDBs in the European political economy has pointed out that over the past two decades European neoliberal regulatory policies have constrained these banks' manoeuvrability significantly, mainly on the grounds of competition and state-aid considerations (Volberding 2016). However, their role in the single market or the European financial system has generally not received scholarly attention.

The financial crisis of 2008, after which these banks moved into the spotlight again, has triggered research emphasizing the counter-cyclical role of development banks in severe downturns-cum-credit-crunches. The former 
EIB vice-president Kollatz-Ahnen (2015), for instance, has focused on state investment banks' impact on growth through the provision of venture capital, while Mazzucato and Penna (2016) have collected evidence for development banks' importance in boosting innovation as well as furthering socioeconomic and environmental progress. While the strong advocacy stance of this literature may partly explain the recent trends around development banking in Europe, they seem less fruitful for connecting them to the European integration process.

When adding the multilateral EIB to this group of banks, one may expect the image to change. An EU institution in its own right (although legally categorized as 'body') and assigned with the task 'to contribute, by having recourse to the capital market and utilizing its own resources, to the balanced and steady development of the common market in the interest of the Community' in the 1957 Treaty of Rome (Treaty of the European Community [TEC], Art. 130), the EIB and its 'essential role in financing European integration' (Dinan 1999: 324; cf. Nugent 2006) is widely acknowledged among scholars of the European Union. However, a closer look reveals that the literature has hardly overcome Robinson's (2009: 669) description of the EIB as a 'neglected institution' that needs 'a serious programme of academic study' to understand the overall 'nature of EU policy making'. Particularly, debates over the public policy role of the EIB have been rare (Honohan 1995; Licari 1969), and despite the EIB having stepped up in public appearance and actual lending in recent years, with political struggles preceding a major capital increase of $€ 10 \mathrm{bn}$ in 2012, scholarly work on it remains sporadic (but see Griffith-Jones and Tyson [2013] for a thorough review of EIB's activities in the EU).

The merit of both Honohan's (1995) and Robinson's (2009) work is its embedding the EIB in the framework of multilevel governance, which enables a less functional-economic but more political view on European development banking. Most importantly, this view highlights the EIB's role in the broader set of European institutions and governance, drawing attention to its relation to both the EC and member states. For instance, peculiar processes of fund implementation in regional policy involving the EIB have made it a central actor in the facilitation of EU integration objectives. As we will show in this article, the EIB's relation to other banks, particularly NDBs, is no less important than its relation to other EU decision-making bodies when seeking to understand its growing reach.

In this context, we find it promising to think about the meaning and transformation of these relations with reference to academic discussions on 'forms of state' and 'core state powers' in the European Union (Caporaso 1996; Genschel and Jachtenfuchs 2016). These debates are usually concerned with how the evolution of the EU fits into longer-term processes of federal state-building and draw attention to the development of specific forms of authority and policy-making capabilities in relation to their member states 
over time (Richardson 2012). Scholarship argues that the lack of fundamental territorial powers on the EU level have led to the rise of a regulatory state, intervening in member states' core functions without developing similar institutions on the supranational level (Majone 1997). The current crisis, however, has again sparked the debate as to what extent the EU moves beyond this description and engages in a new wave of institution building, significantly furthering the integration process (Caporaso et al. 2015; Schimmelfennig 2014).

In this debate, scholars have repeatedly pointed to the underdevelopment of traditional taxing-and-spending functions at the supranational level, and its accompanying low levels of steering capacity and fiscal impact. Our study offers ways to take development banks as quasi-fiscal actors more thoroughly into account in the expansion of EU steering capacity. Clearly, the current political quest to tackle the EU's 'investment gap' creates tensions with a governance mode based on 'rule making replacing taxing and spending' (Majone 1997). However, instead of focussing on an outright fiscal capacity on the European level, our study considers instances of EU capacity-building and policy-making that entail functional equivalences.

To this end, we draw on recent attempts defining states as 'developmental networks states' (Block 2008) or as 'entrepreneurial' (Mazzucato 2015) when they dispose over governmental agencies, including state-owned investment banks, that are 'able to take risks and create a highly networked system of actors that harness the best of the private sector for the national good over a medium- to long-term time horizon' (ibid. : 26). Such structures may not always be visible in the first place, but can emerge in a somewhat hidden fashion circumventing political opposition (Block 2008). However, we prefer the notion of an 'investment state', which highlights the idea that polities develop a governmental infrastructure promoting investment in specific sectors in the economy either through direct spending or through financial techniques mobilizing other public or private funds. This can possibly surpass the mobilization of national powers to compensate for the lack of EU infrastructural powers, as sketched by Genschel and Jachtenfuchs (2016), and create genuine supranational capacities by allowing other policy actors to 'make use of Europe', accessing new political, institutional and budgetary resources (Woll and Jacquot 2010).

Along these lines, we propose to frame the study of development banks in the European political economy. It presents a case for thinking about the gradual ways of institution building, tie-knotting and network formation in the field of economic policy-making, as well as the historical pathway to the EU's crisis responses (Verdun 2015). More precisely, it tries to reveal the stepwise build-up of a durable governance structure over an extended period that increases the EU's power to generate and direct investment through the involvement of (supra)national development banks. 


\section{Economic governance and development banks in the 'old' European political economy, 1957-1988}

Considering the role of development banks in European economic governance, we can characterize a first period from the Treaty of Rome to some years before the Maastricht Treaty as one of institutionalization and relative stability. First, the EIB was mainly a member state bank and its relation to the EC rather muted. Responding to the needs of its shareholders was at the very heart of EIB governance. The board of governors, which must approve of the annual accounts and major policy proposals, consisted and still consists of the national finance ministers; and the board of directors, deciding on the operational strategy and approving all financing operations, is composed of member state delegates with one vote for each country. The European Commission appoints a single delegate to the board of directors.

Just as its focus in the founding period was to function as an infrastructure investment bank, especially for Italy, it became a crucial tool both to integrate new member states and mitigate the concerns of old member states. For instance, when Spain and Portugal were set to enter the Community in 1986, they already had received pre-accession aid and loans from the EIB, which also stepped up lending after accession to buffer established member states' concerns over regional disparities and competition (interview \#9; Bussière et al. 2008). The first three decades of EIB existence were ones of striking a balance between the statutory mandate to serve the Community goals on behalf of the member states and the bank's autonomy that allowed it to shield itself from political lending interference and enabled it to raise capital on the markets (Licari 1969: 194). Nonetheless, the EIB in this period went through some changes in terms of activities, capital increases, and strategic goals, driven both by the enlargement of the Community and the first and second oil crises (Bussière et al. 2008; Clifton et al. 2014). Only few, however, indicate the early tensions of an unfulfilled European investment state.

This is the case because the period in consideration is similarly one of institutionalization in terms of EU fiscal capacity. Most importantly, besides the common agricultural policy the subsequent establishment of structural funds became the main vehicles of discretionary spending and, thus, a fundamental pillar of economic policy-making in the EU. The European Social Fund, already enshrined in the Treaty of Rome, and the European Regional Development Fund, founded in 1975, following Britain's accession, became the largest to tackle unemployment and structural change in the Union (Streeck and Elsässer 2014: 10). But, despite several revenue-based reforms, the cost of enlargement put the EU budget and the structural funds increasingly under pressure (Lindner 2006), leading the EC to search for new means of 
funding. When investment stalled in the years after the first oil crisis, the Commission responded to the Council's call on member states with the implementation of the New Community Instrument $(\mathrm{NCl})$, or 'Ortoli facility'.

The $\mathrm{NCl}$, active between 1977 and 1990 and supplement to the structural funds, enabled the Commission to borrow money that could be lent to regions and member states for infrastructure and energy projects, based on Council approval. Importantly, the Commission neither borrowed the money nor managed the fund on its own, but in conjunction with the EIB (European Union 1999: 89). As far as we can see, the $\mathrm{NCl}$ was (only) the first episode of EC-EIB co-operation resting upon the need for more investment spending in the face of fiscal restraint, whose main precedents were ECinitiated loan applications to the EIB. The $\mathrm{NCl}$ co-operation, however, was little more than a one-off measure, as member states remained by and large the dominant stakeholder group, proposing most of the projects and being the main source of political influence (interview \#10; cf. Föcking 2001; Bussière et al. 2008). ${ }^{4}$

To promote investment, the six founding member states also had development banks at their disposal, though not necessarily on national but regional levels. While Luxembourg was the latest to found one in 1977 Société Nationale de Crédit et d'Investissement (SNCl), of the new member states in this period only Spain (re)founded its development institution Instituto de Credito Oficial (ICO). Their emerging relationship with EU level activities, and the EIB especially, was mainly one of competition in the period under observation. The fact that the EIB had larger financing possibilities and was explicitly designed to operate in the entire EU was as important as the overlap in targeting the same 'underdeveloped' regions. This animosity was particularly strong with respect to $\mathrm{KfW}$, rival in size to the ElB and primus inter pares among European NDBs (interviews \#2; \#8; \#9; Honohan 1995). From its inception, the EIB was aware of this tension and actively aimed at establishing co-operative working relationships with development banks through on-lending and occasional global loan agreements.

This was prominently achieved in Italy, where the EIB - under the auspices of two Italian presidents between 1958 and 1970 - became the key source of finance for the Mezzogiorno, mainly through public financial institutions such as the Cassa per il Mezzogiorno. ${ }^{5}$ However, this sort of early co-operation was never so comprehensive that it would result into some institutionalized form of community economic governance. Rather, when the EIB and NDBs increasingly tapped the same capital markets and started to compete for funds and projects more heavily, competitive concerns loomed larger than the need to expand co-operation. In this sense, Figure 1 roughly illustrates this early web of relations centred around development banks in the European political economy - a rather unconnected and fragmented image with a relatively clear allocation of competences and resources. 


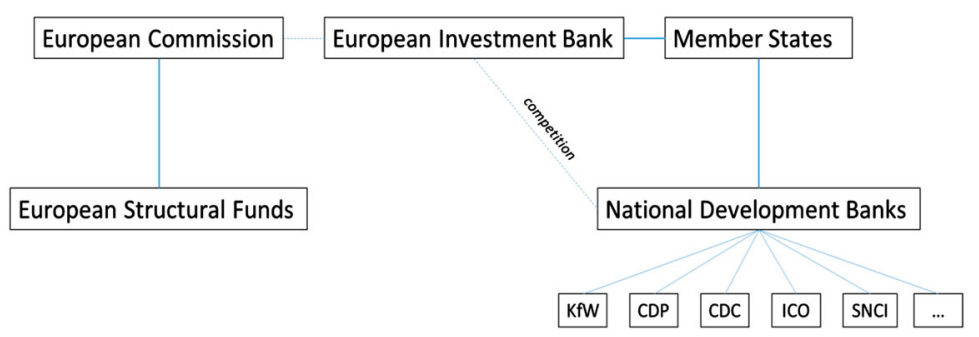

Figure 1. Development banks in the 'old' European political economy, 1957-1988.

\section{The historical trajectory: the gradual transformation of ElB-based public policy interventions 1988-2005}

In the period between 1988 and 2005, we observe a range of policy changes and institutional reforms that can be linked to the initial set-up and simultaneously lay a fundament for the post-crisis era. Several reforms and programmes were implemented in an ad hoc manner but turned out to be long-term qualitative transformations. To begin, the challenges and constraints depicted in the section above led to new initiatives for increasing the impact of the structural funds in the late 1980s. Against the background of the Single European Act, European policy-makers discussed three interwoven concerns: first, concerns over economic growth and rising unemployment; second, concerns over the community's limited own resources; and third, concerns over the efficiency of structural policy (Endo 1999; Stahl 1992). Subsequently, on the initiative of EC President Jacques Delors, the Council adopted an action plan for reforming the funds and doubling its volume within the first multiannual financial framework (MFF) between 1988 and 1992.

One of the respective regulations (EEC 2052/88) highlighted that enhanced co-operation between different funds and policies was necessary to achieve a greater impact, and mainly addressed the EIB's role in promoting the treaty objectives as overlapping with the structural funds. In its subsequent regulation, the Council then stated that 'the Commission must, where necessary, associate the EIB with the preparation of its decisions; whereas the EIB is prepared to cooperate in the implementation of this Regulation, in keeping with its own powers and responsibilities' (EEC 4253/88). In other words, the quest for a more efficient use of the investment instruments at disposal at the European level furnished initiatives to institutionalize a closer co-operation between the Commission and the EIB. Particularly the 1988 reform of structural funds laid the fundament for what we will depict below as the nucleus for an investment state, introducing new governing principles such as 'programming', 'additionality' and 'partnership' (Bachtler and Méndez 2007: 
537). These included the objective to enhance long-term co-operation within a multilevel system, while entailing the use of loans next to subsidies. ${ }^{6}$

In the early 1990s, the gradual rapprochement of EIB and EC intensified. Because of a 'European growth initiative' from 1992 and the following Edinburgh council, the EIB received a capital increase to target infrastructure investment. Importantly, an additional body was also founded to increase the financing power of the EIB (Endo 1999: 194; interview \#9): the European Investment Fund (EIF). First, the EIF was constructed as a joint venture between the EIB, the European Commission, and the financial sector (mostly NDBs) so that its simple establishment foreshadowed a new period of co-operation between these actors (interview \#9). Second, the EIF, set up to fill a perceived gap in the risk financing capacity in the EU, became an active participant in financial markets, employing among other things guarantees to leverage its own funds in financial transactions. As such, the EIF was from its inception linked to financial instruments, a new way of leveraging limited EU budgetary resources.

Introduced into the EU Budget in 1993, financial instruments were first used in the MFF of 1994-1999. The idea underlying these instruments was and is to transform EU resources (e.g. within the structural funds) into financial products (loans, guarantees, equity, etc.) which are then used to support projects promoting EU policies (European Court of Auditors 2016: 11). The crucial difference to grants and subsidies is that they can use private funds to increase leverage and, in case these projects succeed, generate a repayment which can be used for further projects (revolving funds). The main institutions administering these funds were the EIB and the EIF (DG Internal Policies 2012), a fact which brought EIB and EC closer together.

Only a few years later, the 1997 Amsterdam council carried these impulses forward. In its Resolution on Growth and Employment, it called on the EIB and the EIF 'to step up its activities ... promoting investment projects consistent with sound banking principles and practices' and reach into new areas of financing, particularly education, health, urban environment and environmental protection. This led, in July 1997, to the ElB's board approving the Amsterdam Special Action Programme (ASAP), which again furthered the prominence of guarantees and risk assumptions (EIB press release, 12 Dec 1997).

While in both instances the anti-cyclical role of the EIB was very strong, it was pre-conditioned by Europe's turn to institutionalized fiscal restraint through the Stability and Growth Pact. References to balanced budgets and stable macroeconomic conditions abound in the documents and emphasize the need to mobilize new funds promoting investment across the Union. This became particularly clear with the Lisbon Agenda in which the strategy's goals would rely primarily on private sector funds and public-private partnerships. While the Union's role was explicitly said to act as a catalyst, the Council approved of a prominent role of the EIB in achieving the goals of the Agenda 
(Lisbon European Council, 23-24 March 2000). The ElB itself, just as some of its national counterparts, became active players in the liberalization process of the 1990s and early 2000s (Bussière et al. 2008; Clifton et al. 2014).

Interestingly, the political implications of post-socialist transition in this period were also significant for development banking in Europe at large. Besides the founding of the European Bank for Reconstruction and Development (EBRD), many Eastern European countries, such as Slovakia, Slovenia or Croatia followed the idea of public financial institutions for development and founded them in close co-operation with European development banks (cf. interview \#8). ${ }^{7}$ German Reunification also led to an intensified relationship between $\mathrm{KfW}$ and the EIB, with the latter providing funds for the restructuring of the East German economy.

In sum, the EIB grew considerably in importance regarding the management of structural funds, and with crises overshadowing Europe in the early 1990s could increase its capital and expand with a new organizational tool at its disposal. While most of the single measures were ad hoc in their implementation, the new strategies, products and organizational capabilities solidified - and they provided the institutional innovation on which to build in future negotiations. This became strikingly clear when negotiations over the programming period from 2007 onwards started, further increasing the role of financial instruments and co-operation between both the EIB and the EC as well as the EIB/EIF and NDBs. Over the observation period, the programme contributions to financial instruments increased significantly. Non-existent in the first MFF, they added up to $€ 0.57 \mathrm{bn}$ in the 1994-1999 framework, and increased to $€ 1.3 \mathrm{bn}$ in the following framework of 2000-2006.

The proliferation and expanded use of financial instruments had several rationales. First, EU ambitions to influence structural policy were severely limited by the comparatively small size of its budget, a conundrum that financial instruments helped to overcome. In this respect, both the use of leverage as well as the possibility for the return of funds to the EU budget in case of successful project realization were attractive properties of this policy instrument. In the context of the high ambitions of the Lisbon Agenda and an EU budget decreasing in terms of gross national product (GNP), these financial instruments would substantially expand over the course of the next decade, laying further foundations for the 'Juncker Plan'.

\section{The financial crisis, growth of NDBs and network formation 2005-2014}

This third historical section considers the latest innovations and events leading up to the recent Investment Plan for Europe from the perspective of development - or as it was now officially termed - 'promotional' banking. First, the expanded use of financial instruments would be set on a 
larger institutional footing with the 2007-2014 MFF, as new programmes were being designed by the EIB. Called upon by the European Council in December 2005 to 'extend its Structured Finance Facility to research, development and innovation projects and, together with the Commission, explore new ways of using Community funds as levers for EIB loans', the EIB engaged in 'particularly intensive' co-operation with the Commission to develop such instruments (European Investment Bank 2006: 55). Programmes such as 'Jaspers', 'Jeremie' and 'Jessica' signalled the move towards more financial instruments, and hence closer to the Commission; a move not uncontested within the EIB on grounds of autonomy considerations (interview \#10). It reflected a slow cultural change in the self-understanding of the EIB away from the infrastructure development bank of member states towards a promotional bank aligning with the EC. This shift was embraced at the highest level of the institution in the context of the negative discourse on public banks, as it was seen as a means to demonstrate the flexibility and usefulness of the EIB as a policy tool (interview \#9).

After these fundamental innovations in financial instruments in the mid2000s, the financial crisis would provide a substantial boost to their use. Overall, the number of financial instruments supported by the multiannual financial framework would rise to 26,14 of which were administered by the EC and/or the EIB (Núñez Ferrer and Infelise 2015: 15f). Owing to a re-dedication of EU funds, not only the number of instruments but also their volume would grow substantially. From 2011 onwards, about $€ 7$ bn would be rededicated to financial instruments, eventually leading up to $€ 16 \mathrm{bn}$ used during the 2007-2013 MFF instead of an envisaged 12.5bn (EC and EIB 2015: 3; European Court of Auditors 2016: 30). The growth of these measures would require a profound strengthening of inter-institutional co-ordination between the European Commission and the EIB, bringing the two institutions closer together. As stated in a Commission document:

the increased use [of] Financial Instruments in Cohesion Policy has required closer working relationships between the EIB and the European Commission (DG Regio). For the Commission, this has meant a steep learning curve and, to a certain extent, a reliance on EIB expertise in the development and implementation of Fls. (DG Internal Policies 2016b: 10, emphasis added)

The expansion of financial instruments to be administered by not only the EIB but also NDBs now began to set a material incentive for member states to found such a bank. This incentive, in conjunction with the rediscovered role of development banks for weathering a crisis, explains the new wave of founding NDBs in Europe. So, not surprisingly, the Commission highlighted the use of financial instruments and structural funds when approving the creation of these institutions under state aid considerations (European Commission 2014b, 2016b). As the EIB's role has strengthened in the administration of 
European Structural and Investment Funds (ESIF) since 2007, the co-operation between EIB and NPBs has accordingly intensified, because European financial instruments involve NDBs directly, including those administered by the EIB, such as the Risk Sharing Finance Facility and Jeremie or its successors COSME and InnovFin. The principle of subsidiarity, embedded in these instruments, means that EIB/EIF is effectively dependent on NDBs and their local knowledge to implement these programmes. At the same time, NDBs feel pressure by their national governments to access these funds, moving the relation between the two from competition to co-operation (interview \#8).

As in prior periods, the bleak economic conditions called for another European 'growth pact'. In June 2012, the heads of states agreed on a non-binding pact to foster investment without straining national or European budgets. At the heart of it was no 'fresh money', but a $€ 10 \mathrm{bn}$ capital increase for the EIB to boost lending, a EIB-based guarantee initiative ('project bonds'), and a diffuse plan to reallocate some of the structural funds. While demeaned as 'hot air', in combination with the gradual processes of institution building, it laid the latest fundament for an arrangement tying together the trends discussed: The Investment Plan for Europe, through which the EIB expected a further boost of programme contributions to financial instruments up to $€ 35 \mathrm{bn}$.

\section{Into the spotlight: development banks and the Juncker Plan}

When the immediate financial turmoil of the sovereign debt crisis somewhat retreated, concerns about sluggish growth and low investment moved to the forefront around the European elections of 2014. Shortly after his election, Jean-Claude Juncker announced the Investment Plan for Europe and its core piece, EFSI. A compromise between those political parties seeking a strong public stimulus program funded by the EU, and those committed to limit the size of the EU budget (Spiegel 2014), the plan appears as a merger of the preceding steps in governance through development banking. While it was launched jointly by the Commission and the EIB, it gave full operational control to the EIB with the EFSI steering board located within the bank. The EIB now seemed the evident choice for policy-makers to administer strategic funds: it not only had extensive experience with respect to public infrastructure projects and was entrusted with other funds by the Commission, it was also largely exempted from European state aid rules, permitting a relatively low bureaucratic burden during the implementation phase (interview \#3; \#9).

In terms of logic, the EFSI works very much along the lines of financial instruments. It entails guarantees of $€ 16 \mathrm{bn}$ from the EU budget and $€ 5 \mathrm{bn}$ from the EIB that, combined, allow the EIB and the EIF to employ €63bn of capital (leverage of 1:3). These $€ 63 \mathrm{bn}$ are positioned to mobilize private and public investment of $€ 315 \mathrm{bn}$ in total (leverage of 1:5). As a recent report by the EU Committee of the Regions put it, the EFSI is 'a dedicated non pre- 
allocated Financial Instrument mechanism to leverage investment [and] another recognition of the potential role of EU financial instruments in delivering growth-friendly expenditures' (Núñez Ferrer and Infelise 2015: 9). In other words, the EFSI opens a channel to increase investments through leveraging limited budgetary resources and combining them with the levers of the EIB and the EIF - a mechanism that in our view constitutes features of an investment state through the creation of governmental infrastructures.

The Investment Plan also draws heavily on the involvement of NDBs, their technical expertise and capacity in identifying investment opportunities being singled-out by the Commission as important capabilities for the success of the plan. A largely unanticipated role would be played by NDBs when it came to increase the fund's financing capacities. In its first communique in November 2014, the Commission asked member states 'to join this initiative, including by providing further funding to the European Fund for Strategic Investments' (European Commission 2014: 16). In the following eight months, such additional financing would only be forthcoming from NDBs pledging funds to support EFSI. Beginning with the German KfW in February 2015, which pledged $€ 8 \mathrm{bn}$, overall eight development banks would pledge about $€ 40 \mathrm{bn}$ in total. NDBs became particularly more active once it became clear that member states would not contribute any or any significant resources to the plan. Based upon the subsidiarity principles, however, these funds were not transferred to the EIB, but instead were lending commitments NDBs made themselves in the context of projects financed by EFSI, which allowed them to maintain control over their funds (interview \#2; \#3).

Through its provision of guarantees, EFSI also permitted NDBs to expand their activities and organizational capabilities. The opportunity to regain some of the momentum on the political scene by becoming pivotal actors in the process of EFSI motivated the large and well-established NDBs in Europe to act. In a joint letter to the Commission in April 2015, the large development banks of France, Germany, Italy, Poland and Spain, as well as the EIB announced that they 'are prepared to contribute to the EU Investment Plan' and 'ready to expand our activities with the complementary support of the increased EIB Group risk capacity'. ${ }^{8}$ Such activities would include project finance, public-private partnerships for infrastructure projects as well as increasing engagement in securitization (BGK et al. 2015). However, they made these statements conditional on being safeguarded of EU regulatory interference in their activities particularly regarding state aid regulations.

In July 2015, the Commission assuaged these concerns. Encouraging the use of existing NDBs or founding new ones in the context of EFSI (European Commission 2015b), it clarified that investments by NDBs were to be largely exempted from state aid rules (ibid.: 6) and covered by block exemptions or de minimis rules (EFSI SB 2016). ${ }^{9}$ Given that state aid rules are differently 
interpreted in each country, this new general framework makes co-operation between different NDBs and the EIB much easier (interview \#7). Furthermore, the regulation provided by the EC in July 2015 helped to alleviate fears of the EFSI taking up business of NDBs. The Commission, aware of competition between the EIB and NDBs, stated that 'EFSI should not be a substitute for private market finance or products provided by national promotional banks or institutions but should instead act as a catalyst for private finance' (EU 2015). These concerns being soothed by the Commission, the large NDBs in Europe continued to offer their support, announcing 'further joint instruments and initiatives ... [that] could be developed by joint working groups among NPBs and the EIB in connection with the EFSI' (BPI et al. 2015: 10). ${ }^{10}$ Summarizing, the establishment of EFSI in 2014 further catalysed the integration of the activities of NDBs with the EIB and the EC. This increase resides in the reconfiguration and explicit articulation of their relationship with the aim to calm institutional rivalry (interview \#2).

Considering these changes in the European economic governance framework cumulating since 1988, we can now assess the figuration of development banking in the 'new', post-2008 European political economy. Figure 2 summarizes the expanding network of relationships via specific institutional and financial innovations, showing it as much more intertwined and connected than in the 'old' European political economy. Independent of the possible material impact on European investment, one can arguably see the formation of a network based on the premise to mobilize and leverage funds, share risks, and co-operate to facilitate investment. Most importantly, and in contrast to Figure 1, co-operation is programmatic, based upon multilevel networks and coalitions, which though not eliminating competing goals and frictions, group around furthering investment more stringently than before.

These institutional ties between the EIB and the NDBs are likely to solidify owing to reforms and regulations following the Investment Plan for Europe. The increasing interaction between NDBs and the EIB through these financial instruments has been placed on a new level by the reconfiguration of

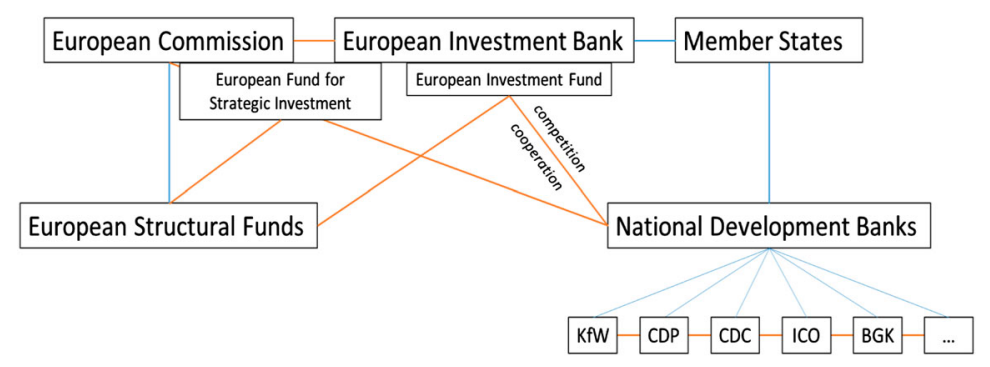

Figure 2. Development banks in the 'new' European political economy. 
structural funds into European Structural and Investment Funds in the MFF 2014-2020. ${ }^{11}$ Encouraging the use of financial instruments that can be employed to complement projects within EFSI (European Commission 2015a, 2016), these reforms increase the areas of co-operation among NDBs and the EIB. Shared management and implementation of structural funds-based financial instruments lie at the heart of this co-operation (DG Internal Policies 2016a, 12f); a construction NDBs have actively engaged in (interview \#8). In the period of 2014-2016, ESIF are supposed to account for 14 per cent of EU-wide public investment (European Commission 2015: 4). Furthermore, in September 2016 the EC proposed an extension of the Investment Plan until 2020 and a bolstering of the $€ 16 \mathrm{bn}$ guarantee by $10 \mathrm{bn}$. The EIB itself plans to contribute an additional $2.5 \mathrm{bn}$, aiming to mobilize a total of $500 \mathrm{bn}$ (instead of $315 \mathrm{bn}$ ) over the next years. The Commission has repeated here that:

In partnership with the EIB, NPBs play a key role in the implementation of the Investment Plan, including the EFSI, as their product ranges, local knowledge and geographical reach are complementary. They will remain key in the extended EFSI, including in co-financing projects with the EIB and other investors. (European Commission 2016)

This statement speaks to the joint role of EIB and NDBs in bringing about the desired investment push in the European Union based on co-financing and complementarity. The multilevel network of development banks, linked through financial instruments is actively fostered by the European Commission, as their joint activities increase its governance capabilities, gradually 'unmuting' the relationship with the EIB as the 'bank of the EU'.

\section{Conclusions: towards a hidden European investment state?}

When focusing on the evolution of development banking in Europe, one can observe the stepwise transformation of European economic governance in which the European Union has developed a governmental infrastructure that aims at facilitating investment through quasi-fiscal actors. In this process, the European Commission has gradually expanded discretion over investment vehicles, including the EIB. Through channelling its limited public budget into financial instruments this development has created stronger institutional ties between the European Commission, the EIB including the $\mathrm{EIF}$, and national development banks. As this analysis shows, the Investment Plan for Europe is less of a brand-new counter-cyclical plan, but the latest stage in this long-term evolution based on the idea of leveraging constrained public budgets.

While it is unclear whether the Investment Plan can really deliver the promised investment impact (Godin 2016; Rubio et al. 2016), what is pivotal in our perspective is how it has brought together rather disconnected aspects of investment vehicles into a more coherent, network-based governance 
framework. We call this the nucleus of a European investment state, as it provides a multilevel governmental infrastructure focused on furthering investment. Based on the principles of subsidiarity and complementarity, this structure signals an expansion of European core powers that builds on but also holds material incentives for - member states founding or engaging development banks.

Two caveats, however, should be in place. First, given that the executive powers of this investment state are development banks, its core structures remain somewhat hidden with unclear and at least variegated effects on its material impact. In this sense, second, it differs markedly from an investment state of the old Keynesian type. Through financial instruments, the EU seeks to realize a greater fiscal impact than the size of its limited budget permits. Taking the form of guarantees and equity, this investment state works based on public-private partnerships and leveraging, and therefore requires less direct state spending. In this sense, it is less an endeavour in democratic economic government, but remains in the vein of technocratic governance.

It is important to note that this network, which remains work in progress, is not organized in a hierarchical way. As we demonstrate above, the EIB (the central node combining the EC, member states and NDBs) is not under the control of a single player and furthermore pursues its own interest. National development banks, conversely, also pursue their own interests as well as those of member states, when participating in these investment schemes. These actors are making use of Europe to expand their legitimacy and their own strategic positioning in policy processes. Thus, despite the demise of state banking in traditional terms, one cannot avoid the impression that the gradual increase of importance of both the EIB and NDBs rest upon a stepwise interest alignment, crucially between the Commission and member states.

The simple reason, as occurs to us, is that development banks have continuously provided a means of economic policy making in the face of fiscal restraint. Nonetheless, it is unclear how stable or vulnerable the depicted nucleus is. Consolidating and expanding the governmental infrastructure will depend on the continued material incentives all the actors involved in the investment state derive. Should financial instruments turn out to burden state budgets, rather than relieving them, or be tainted by scandals of corruption, perceived advantages might diminish and the coherence of the nucleus wane. Most definitely, the political dynamics around European development banking will provide fruitful ground for research and debate for years to come. 


\section{Notes}

1. According to EU regulation, state-owned development banks are defined as 'legal entities carrying out financial activities on a professional basis which are given a mandate by a member state or a member state's entity at central, regional or local level, to carry out development or promotional activities' (EU 2015: 10).

2. Calculations based on each institutions' financial report from 2008 and 2015 respectively.

3. It is worth noting that the proponents of this analysis have also criticized the ElB for not fully employing its capabilities in the crisis and lagging behind a true counter-cyclical response to the economic recession.

4. An important qualification of the view presented here, however, can be found in Article 19 (ex Art. 21) of the EIB statute. It states that a project facing opposition from the EC can only be financed when the Board of Directors overrides the EC position in a unanimous vote, giving the EC more influence on ElB policy than our assessment of this period suggests.

5. See, for instance, http://www.eib.org/infocentre/blog/all/a-drive-along-italysroads.htm?lang=-en (accessed 1 June 2017).

6. The EIB welcomed these changes as part of their own adjustments to a changing economic and political environment, highlighting the need for the integration of loans to avoid 'poorly planned and badly managed projects' (European Investment Bank 1988: 15; see also Bussière et al. 2008: 206ff.).

7. This interaction of Western and Eastern European development banks also laid the foundation for an institutionalization of these collaborations in the Network of European Financial Institutions for SMEs founded in 1999 (interview \#8).

8. These six institutions also set up the equity fund Fonds Marguerite as part of the European Economy Recovery Plan (EERP) in 2010, whose main goal is to further infrastructure investment through the involvement of private and public institutional investors. The CDC, CDP and KfW also share an office in Brussels.

9. This position seems to have been a compromise between DG Regio and other expansionary forces within the EC and DG Competition, the guardian of state aid rules (for a thorough discussion of the latter see Volberding [2016]).

10. This is also an expression of the clout of the grown community of NDBs in Brus-sels, which not only intensified their co-operation with the EIB and the EIF, but also formed closer ties among each other to increase its influence upon rule making processes in the EU. While their formal co-operation was instituted in 1999 with the Network of European Financial Institutions for SMEs (NEFI), it has strongly deepened in the crisis and found new institutional venues, e.g. in the Long Term Investor Club (founded in 2009) or in its offshoot European Association of LongTerm Investors (ELTI) (interview \#7).

11. This reconfiguration also involves regional development banks, which benefit directly from European regional funds, as championed by DG Regio.

\section{Acknowledgements}

An earlier version of this article was presented at the 28th European Association for Evolutionary Political Economy (EAEPE) Conference in Manchester, 3-5 November 2016, and the 'Finance for Growth and Development' Workshop at the University of Cambridge, 29 November 2016. We thank all participants as well as two anonymous reviewers for their time and their critical engagement with our argument. Sophia Spornraft has provided valuable research assistance. 


\section{Disclosure statement}

No potential conflict of interest was reported by the authors.

\section{Notes on contributors}

Daniel Mertens is a postdoctoral researcher in international political economy at Goethe University, Frankfurt am Main.

Matthias Thiemann is assistant professor of European public policy at Sciences Po, Paris.

\section{ORCID}

Daniel Mertens (D) http://orcid.org/0000-0002-2194-8293

\section{References}

Bachtler, J. and Méndez, C. (2007) 'Who governs EU cohesion policy? Deconstructing the reforms of the structural funds', JCMS: Journal of Common Market Studies 45 (3): 535-64.

BGK, et al. (2015) 'Letter of European development banks to the President of the European Commission' 23 April 2015.

Block, F. (2008) 'Swimming against the current: the rise of a hidden developmental state in the United States', Politics \& Society 36(2): 169-206.

$\mathrm{BPI}, \mathrm{CDP}$, ICO and KfW (2015) SME Investment and Innovation. France, Germany, Italy and Spain. Maisons-Alfort Cedex/ Rome/ Madrid/ Frankfurt: bpifrance/Cassa depositi e prestiti SpA/ Instituto de Crédito Oficial/ KfW Bankengruppe.

Bussière, É., Dumoulin, M. and Willaert, É. (2008) The Bank of the European Union. The EIB, 1958 -2008, Luxembourg: EIB.

Caporaso, J.A. (1996) 'The European Union and forms of state: westphalian, regulatory or post-modern?', JCMS: Journal of Common Market Studies 34(1): 29-52.

Caporaso, J.A., Kim, M.-h., Durrett, W.N. and Wesley, R.B. (2015) 'Still a regulatory state? The European Union and the financial crisis', Journal of European Public Policy 22(7): 889-907.

Clifton, J., Díaz-Fuentes, D. and Revuelta, J. (2014) 'Financing utilities: how the role of the European investment bank shifted from regional development to making markets', Utilities Policy 29: 63-71.

DG Internal Policies. (2012) Overview of Financial Instruments used in the EU Multiannual Financial Framework Period 2007-2013 and the Commission's Proposals for 20142020. Brussels: European Parliament.

DG Internal Policies. (2016a) New Financial Instruments and the Role of National Promotional Banks, Brussels: European Parliament.

DG Internal Policies. (2016b) Review of the Role of the EIB Group in European Cohesion Policy, Brussels: European Parliament.

Dinan, D. (1999) Ever Closer Union: An Introduction to European Integration, Boulder: Lyenne Rienner.

EC and EIB. (2015) A Sustainable Way of Achieving EU Economic and Social Objectives. Financial Instruments, Brussels, Luxembourg: European Commission and European Investment Bank. 
EFSI SB, European Fund for Strategic Investment Steering Board. (2016) 'Rules applicable to operations with investment platforms and national promotional banks or institutions.' Meeting SB 10/16, 18 February 2016.

Endo, K. (1999) The Presidency of the European Commission Under Jacques Delors: The Politics of Shared Leadership, Basingstoke: Macmillan.

European Commission. (2014a) 'An Investment Plan for Europe', COM(2014) 903 Final, 26 Nov, Brussels: Commission of the European Communities.

European Commission. (2014b) 'State aid: Commission approves creation of Portuguese development financial institution', Press Release IP/14/1214, 28 October, Brussels: EC.

European Commission. (2015a) 'Investing in jobs and growth - maximising the contribution of European Structural and Investment Funds', COM(2015) 639 Final, 14 Dec, Brussels: Commission of the European Communities.

European Commission. (2015b) 'Working together for jobs and growth: The role of National Promotional Banks (NPBs) in supporting the Investment Plan for Europe', COM(2015) 361 Final, 22 July, Brussels: Commission of the European Communities.

European Commission. (2016a) 'State of the Union 2016: The European Fund for Strategic Investments (EFSI) - Frequently Asked Questions', COM MEMO 16/2983, 14 Sep, Brussels: Commission of the European Communities.

European Commission. (2016b) 'State aid: Commission approves creation of Malta Development Bank', Press Release IP/16/2881, 24 August, Brussels: EC.

European Court of Auditors (2016) Implementing the EU Budget Through Financial Instruments - Lessons to be Learnt From the 2007-2013 Programme Period, Luxembourg: European Union.

European Investment Bank. (1988) 'ElB Annual Report 1987', 1988, Luxembourg: EIB.

European Investment Bank. (2006) 'ElB Group Activity Report 2005', Luxembourg: EIB.

European Union. (1999) The European Union Encyclopedia and Directory, London: Europa Publications.

European Union. (2015) 'Regulation (EU) 2015/1017 of the European Parliament and of the Council of 25 June 2015 on the European Fund for Strategic Investments, the European Investment Advisory Hub and the European Investment Project Portal'. http://eur-lex.europa.eu/legal-content/EN/TXT/HTML/?uri=CELEX:32015R1017.

Föcking, J. (2001) Die Darlehenspolitik der Europäischen Investitionsbank: Eine Untersuchung des Zusammenhangs Zwischen Machtstrukturen und Mittelvergabe, Frankfurt am Main: Lang.

Genschel, P. and Jachtenfuchs, M. (2016) 'More integration, less federation: the European integration of core state powers', Journal of European Public Policy 23(1): 42-59.

Godin, R. (2016) 'Has the Juncker Plan really boosted investment in Europe?', available at https://www.euractiv.com/section/euro-finance/news/has-the-juncker-plan-reallyboosted-investment-in-europe/ (accessed 18 November 2016)

Griffith-Jones, S. and Cozzi, G. (2016) 'Investment-led growth: a solution to the European crisis', in M. Mazzucato and M. Jacobs (eds), Rethinking Capitalism: Economic Policy for Sustainable and Equitable Growth, Hoboken: Wiley-Blackwell, pp. 119-33.

Griffith-Jones, S. and Tyson, J. (2013) 'The European Investment Bank: Lessons for Developing Countries', UNU-WIDER Working Paper 2013/019, United Nations University.

Honohan, P. (1995) 'The public policy role of the European investment bank within the EU', JCMS: Journal of Common Market Studies 33(3): 315-30. 
Kollatz-Ahnen, M. (2015) 'The rise of state investment banks', in M. Mazzucato and C.C. Penna (eds), Mission-oriented Finance for Innovation. New Ideas for Investment-led Growth, London, New York: Rowman \& Littlefield, pp. 111-18.

Licari, J. (1969) 'The European investment bank', JCMS: Journal of Common Market Studies 8(3): 192-215.

Lindner, J. (2006) Conflict and Change in EU Budgetary Politics, London, New York: Routledge.

Majone, G. (1997) 'From the positive to the regulatory state: causes and consequences of changes in the mode of governance', Journal of Public Policy 17(2): 139-67.

Mazzucato, M. (2015) The Entrepreneurial State. Debunking Public vs. Private Sector Myths, New York: Public Affairs.

Mazzucato, M. and Penna, C.C. (2016) 'Beyond market failures: the market creating and shaping roles of state investment banks', Journal of Economic Policy Reform 19(4): 305-26.

Nugent, N. (2006) The Government and Politics of the European Union, Basingstoke: Palgrave Macmillan.

Núñez Ferrer, J. and Infelise, F. (2015) 'Financial Instruments in Support of Territorial Development', 2015, European Union.

Richardson, J. (ed) (2012) Constructing a Policy-making State? Policy Dynamics in the EU, Oxford: Oxford University Press.

Robinson, N. (2009) 'The European investment bank: the EU's neglected institution', JCMS: Journal of Common Market Studies 47(3): 651-73.

Rubio, E., Rinaldi, D. and Pellerin-Carlin, T. (2016) 'Investment in Europe: Making the Best of the Juncker Plan', JDI Studies and Reports 109, Paris, Berlin: Jacques Delors Institute.

Schimmelfennig, F. (2014) 'European integration in the euro crisis: the limits of postfunctionalism', Journal of European Integration 36(3): 321-37.

Seikel, D. (2014) 'How the European Commission deepened financial market integration. The battle over the liberalization of public banks in Germany', Journal of European Public Policy 21(2): 169-87.

Shonfield, A. (1965) Modern Capitalism. The Changing Balance of Public and Private Power, London: Oxford University Press.

Spiegel, P. (2014) 'Jean-Claude Juncker to unveil €315bn EU programme', Financial Times, 24 November.

Stahl, G. (1992) 'Die Europäische Gemeinschaft vor einer erneuten Finanzkrise?', Wirtschaftsdienst 72(2): 80-84.

Streeck, W. and Elsässer, L. (2014) 'Monetary Disunion: The Domestic Politics of Euroland', MPIfG Discussion Paper 14/17, 2014, Köln: Max-Planck-Institut für Gesellschaftsforschung.

Verdier, D. (2000) 'The rise and fall of state banking in OECD countries', Comparative Political Studies 33(3): 283-318.

Verdun, A. (2015) 'A historical institutionalist explanation of the EU's responses to the euro area financial crisis', Journal of European Public Policy 22(2): 219-37.

Volberding, P. (2016) National Development Banks and the Rise of Market-Based Protectionism in Europe, unpublished manuscript.

Woll, C. and Jacquot, S. (2010) 'Using Europe: strategic action in multi-level politics', Comparative European Politics 8(1): 110-26.

Zysman, J. (1983) Governments, Markets, and Growth. Financial Systems and the Politics of Industrial Change, Oxford: Martin Robertson. 


\section{Appendix}

Table A1. List of interviewees for this article.

\begin{tabular}{llll}
\hline 1 & NGO official, EIB expert & 18 May 2016 & Brussels \\
2 & KfW official & 24 May 2016 & Frankfurt \\
3 & Former EC official & 27 May 2016 & Berlin \\
4 & EIF officials & 8 June 2016 & Luxembourg \\
5 & KfW official & 22 June 2016 & Frankfurt \\
6 & MEP / ECON member & 20 June 2016 & Brussels \\
7 & EIB official & 6 July 2016 & Luxembourg \\
8 & KfW official & 1 August 2016 & Brussels \\
9 & Former EIB official & 2 August 2016 & Luxembourg \\
10 & Former EIB official & 29 September 2016 & Berlin \\
\hline
\end{tabular}

